\title{
Penerapan LKS Eksperimen Berbasis Pendekatan Scientific Melalui ICT Dalam Model Pembelajaran Kooperatif Tipe Jigsaw Modifikasi Terhadap Pencapaian Kompetensi Fisika Siswa Kelas X MIA SMAN 6 Padang
}

\author{
Diana Hariyanti $^{(1)}$, Masril $^{(2)}$, Hidayati ${ }^{(2)}$ \\ ${ }^{1)}$ )Mahasiswa Pendidikan Fisika, FMIPA Universitas Negeri Padang \\ ${ }^{2)}$ Staf Pengajar Jurusan Fisika, FMIPA Universitas Negeri Padang \\ hariyantidiana@gmail.com
}

\begin{abstract}
One cause of low achievement of students in the competence of SMAN 6 Padang is learning in school is not optimal, both in terms of learning and in experiments activities. To overcome these problems, the authors designed experiments LKS in oriented scientific approach thought ICT in cooperative learnig model jigsaw modified. Therefore, the authours propose the purose of this study was to investigate the application of LKS effect scientific axperiments through ICT based the approach in cooperative learning type jigsaw modifications to the attainment of knowledge and competence skills of students of class X MIA SMAN 6 Padang to achive these objectives the study took two classes samples by purposive sampling technique. To evaluate the lessons, the authors conducted a competency assessment for the third. Attitude competency assessment through observation technique with instruments such as observation sheet. For knowledge competency assessment through written tests in the form of multiple choice test. As for competency skills through technical performance of the instrument in the form of scoring rubric. Based on an analysis of data on each of the competencies acquired that: there are differences in attitudes competence value fot both classes. In the knowledge acqured competence $t_{h}{ }^{\prime}=3,962, t_{\text {table }}=2,00$ on the rea level of 0,05, meaning that the value of $t_{h}>t_{\text {tabel }}$ Hi received with great influence of 0,39\%. On the skill competencies $t_{h}=3,96 t_{\text {table }}=2,00$ on the rea level of 0,05, meaning that the value of $t_{h}>t_{\text {tabel }}$ Hi received with great influence of 93,10\%. Based on the Results obtained can be concluded there is a significant impact LKS application of scientific experiments through ICT base approach in a cooperative learning type jigsaw modifications to the attainment of knowledge and competence skills of class $X$ MIA SMAN 6 Padang with 95\% significance level.
\end{abstract}

Keywords : : LKS experimental, Scientific approach, Cooperative Learning Type Jigsawm of Modification, ICT

\section{PENDAHULUAN}

Fisika merupakan salah satu cabang sains dan merupakan dasar dari berbagai cabang disiplin ilmu lain terutama dalam bidang teknologi. Hal ini menunjukan bahwa fisika memegang peranan penting dalam menciptakan teknologi baru agar tidak terbelakang dari dunia Ilmu Pengetahuan dan Teknologi (IPTEK). Semakin pesatnya perkembangan ilmu pengetahuan dan teknologi, maka pemerintah perlu meningkatkan kualitas pendidikan untuk mengimbanginya, sesuai dengan tuntutan Kurikulum 2013 yaitu diharapkan peserta didik kreatif, aktif, berfikir kristis, dan mandiri serta mampu untuk bersaing dengan bangsa-bangsa lain.

Menyadari pentingnya mata pelajaran fisika, pemerintah telah melakukan upaya agar kualitas pembelajaran itu dapat meningakat. Upaya-upaya yang dilakukan pemerintah seperti:1) merevisi kurikulum dari KTSP menjadi Kurikulum 2013 yang lebih menekankan kepada karakter dari peserta didik, 2) perubahan dalam pendekatan pembelajaran (dari teacher center menjadi student center), 3) menyiapkan sarana dan prasarana yang dibutuhkan sekolah seperti laboratorium, pustaka, ICT (Information and Communication Technologies), dan sumber belajar lain. 4) meningkatkan profesional guru melalui penataran, diklat, dan sertifikasi guru.

Seiring upaya yang telah dilakukan pemerintah tersebut, kenyataan yang dijumpai di lapangan belum menunjukkan hasil yang memuaskan. Hal ini masih terlihat dari mata pelajaran Fisika masih belum mencapai KKM (Kriteria Ketuntasan Minimal) yang telah ditetapkan. Hasil observasi melalui wawancara dengan salah satu guru fisika di SMAN 6 Padang diperoleh penjelasan penyebab pencapaian kompetensi fisika siswa belum mencapai KKM antara lain:1) pembelajaran masih berpusat pada guru walaupun sudah menerapkan Kurikulum 2013，2) pendekatan scientific dalam model pembelajaran yang digunakan oleh guru belum optimal, 3) guru jarang memfasilitasi siswa dalam pembelajaran kelompok, 4) LKS (Lembar Kerja Siswa) yang dipakai siswa di sekolah berisi ringkasan materi dan soal latihan, sedangkan kegiatan praktikum dalam LKS berisi judul, tujuan, alat dan bahan serta langkah kegiatan belum ada 
langkah-langkah scientific, 5) buku paket yang digunakan guru belum berorientasi pada pendekatan scientific, 6) sarana sekolah untuk menunjang penggunaan media pembelajaran masih terbatas, contohnya OHP proyektor hanya ada satu yang bisa digunakan, 7) fasilitas Laboratorium Fisika cukup memadai tetapi kegiatan praktikum pada mata pelajaran Fisika belum terlaksana, 8) Pembelajaran menggunakan ICT belum maksimal walaupun sudah tersedia fasilitas ICT.

Untuk mengatasi permasalahan tersebut perlu dilakukan perbaikan-perbaikan dalam pembelajaran Fisika. Khusus untuk masalah laboratorium, diperlukan LKS yang sesuai dengan Kurikulum 2013 berorientasi pendekatan scientific. LKS tersebut dapat dipelajari siswa melalui ICT. Tujuan penggunaan ICT dalam pembelajaran agar peserta didik dapat belajar dengan akses yang lebih mudah dan dapat memungkinkan belajar dimana dan kapan saja.

LKS adalah lembaran-lembaran berisi tugas yang harus dikerjakan oleh peserta didik, lembaran kegiatan biasanya berupa petunjuk, langkah-langkah untuk menyelesaikan tugas ${ }^{[1]}$. LKS dapat dibedakan atas dua macam, yakni LKS eksperimen dan LKS non eksperimen ${ }^{[2]}$. LKS eksperimen merupakan LKS yang dijadikan pedoman untuk melaksanakan kegiatan laboratorium atau melakukan eksperimen dan dapat memuat semua jenis keterampilan proses. LKS eksperimen digunakan untuk membimbing siswa dalam berpraktikum cocoknya dengan memberikan pendekatan laboratorium, dimana siswa lebih aktif, terampil dan lebih mudah memahami konsep materi yang dipelajari.

Dalam pelaksanaan Kurikulum 2013, pembelajaran yang dilakukan dituntut menggunakan ICT. ICT dalam proses pembelajaran diharapkan dapat memberikan kemudahan dan kesempatan yang lebih luas kepada peserta didik dalam belajar. Pemanfaatan ICT dalam pembelajaran salah satunya dapat berupa pemanfaatan internet sebagai media pembelajaran yang memungkinkan siswa belajar secara mandiri yang dapat diakses secara online. Perkembangan teknologi pada zaman sekarang, penggunaan internet menjadi hal yang biasa bagi siswa. Oleh karena itu guru juga perlu menikmati penggunaan internet dan mengikuti trend dalam desain dan informasinya yang digunakan dalam proses pembelajaran. Dalam pembelajaran online, guru perlu membantu peserta didik mengembangkan strategi untuk mengerjakan pekerjaan mereka secara efisien dan memperoleh informasi dan keterampilan yang mereka butuhkan untuk melengkapi pelajarannya ${ }^{[3]}$. Guru harus merasa nyaman melakukan browsing web untuk mendapatkan informasi baru yang dapat digunakan dalam proses pembelajaran.

Selain itu, dengan bantuan ICT proses penyampaian dan penyajian materi pembelajaran maupun gagasan dapat menjadi lebih menarik, menyenangkan, dan praktis. Tujuan penggunaan ICT dalam pembelajaran agar siswa dapat belajar dengan akses yang lebih mudah dan dapat memungkinkan belajar dimana saja dan kapan saja. LKS eksperimen untuk kegiatan laboratorium dapat dipelajari siswa dalam ICT. Pembelajaran menggunakan LKS dengan memanfaatkan ICT dapat menjadi lebih efektif dan siswa dapat belajar dimana saja dengan akses yang lebih mudah. Dalam LKS eksperimen berbasis pendekatan scientific melalui ICT, siswa belajar menggunakan HP atau laptop yang di dalamnya siswa dapat mengakses animasi, video kegiatan praktikum, dan materi yang menunjang siswa dalam kegiatan pembelajaran.

Dalam mengimplementasikan LKS eksperimen melalui ICT perlu diterapkan dengan suatu model pembelajaran agar pembelajaran yang dilakukan dapat mencapai tujuan yang diharapkan. Salah satu model pembelajaran yang digunakan adalah model pembelajaran kooperatif tipe jigsaw, karena model ini dapat meningkatkan aktivitas siswa melalui kerja sama antar siswa dalam proses pembelajaran dan dalam kegiatan laboratorium. Model pembelajaran kooperatif tipe jigsaw merupakan model belajar kooperatif dengan cara siswa belajar dalam kelompok kecil yang terdiri dari empat sampai enam orang secara heterogen dimana siswa belajar secara bekerja sama yang saling berketergantungan positif dan bertanggung jawab secara mandiri. Model pembelajaran koopertif tipe jigsaw, guru membagi satuan informasi yang besar menjadi komponen-komponen yang lebih kecil ${ }^{[4]}$. Pembelajaran kooperatif tipe jigsaw adalah suatu tipe pembelajaran kooperatif yang terdiri dari beberapa anggota dalam satu kelompok yang bertanggung jawab atas penguasaan bagian materi belajar dan mampu mengajarkan materi tersebut kepada orang lain dalam kelompoknya ${ }^{[5] .}$.

Model pembelajaran kooperatif tipe jigsaw lebih baik diterapkan dibandingkan metode konvensional atau ceramah, hal ini sesuai dengan peneliti lain bahwa pembelajaran kooperatif jigsaw adalah metode yang lebih efektif dalam hal prestasi akademik daripada pembelajaran tradisional ${ }^{[6]}$. Model pembelajaran kooperatif tipe jigsaw memiliki unsur akuntabilitas dan saling ketergantungan setiap siswa, hal tersebut tidak ditemukan dalam metoda ceramah $^{[7]}$. Model pembelajaran kooperatif tipe jigsaw disarankan dapat diterapkan dalam berbagai mata pelajaran dan tingkat kelas sehingga metode pembelajaran kooperatif tipe jigsaw dapat digeneralisasikan $^{[5]}$. Salah satu mata pelajaran yang dapat menerapkan model pembelajaran kooperatif tipe jigsaw adalah mata pelajaran fisika.

Model pembelajaran kooperatif tipe jigsaw merupakan salah satu model pembelajaran kooperatif yang paling fleksibel, sehingga dapat dimodifikasi untuk mengubah beberapa detil implemetasi tetapi 
tidak mengubah dasar dari model pembelajaran tersebut $^{[8]}$. Dalam kegiatan laboratorium model pembelajaran kooperatif tipe jigsaw dimodifikasi agar pelaksanaan praktikum dapat berjalan meskipun dengan alat praktikum yang terbatas. Pemodifikasian ini dikarenakan dalam satu pertemuaan tidak dapat menyelesaikan semua praktikum untuk masingmasing kelompok, sehingga modifikasi jigsaw ini tidak menghilangkan unsur jigsaw, terutama kelompok asal dan kelompok ahli. Pemodifikasian jigsaw hanya untuk mempermudah pelaksanaan praktikum dengan waktu yang efektif. Ilustrasi pelaksanaan model pembelajaran kooperatif tipe jigsaw modifikasi dapat dilihat pada Gambar 1.

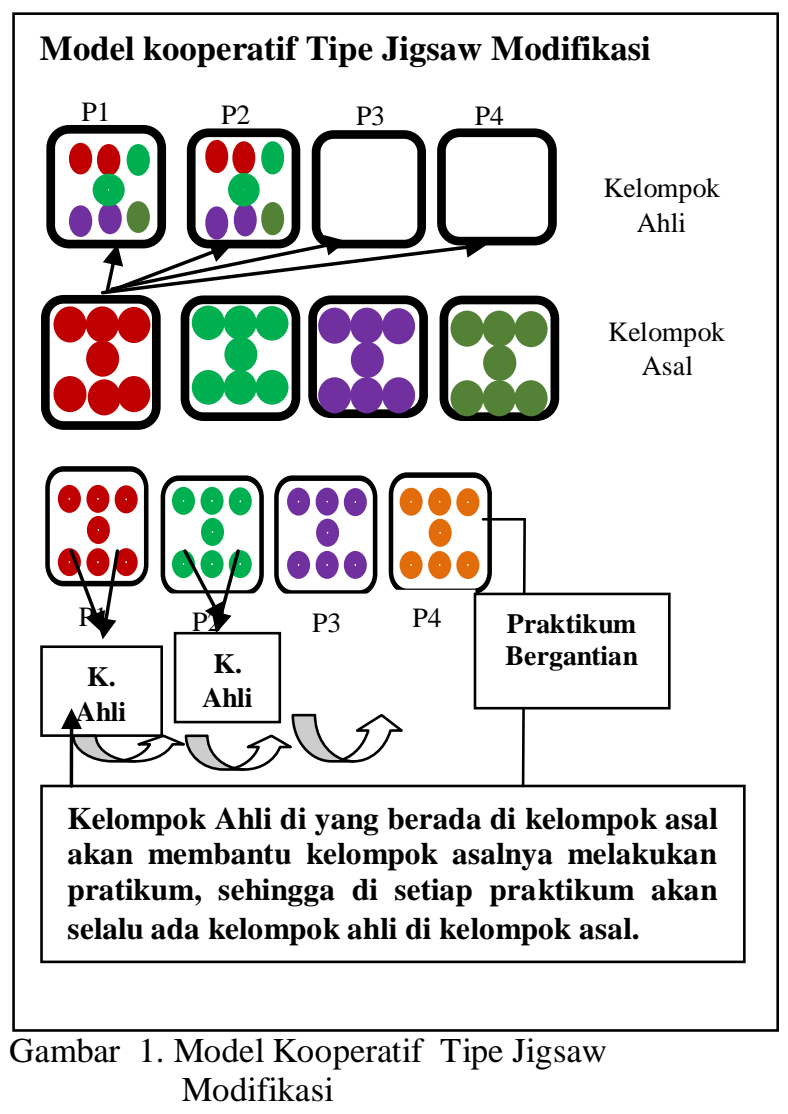

Berdasarkan Gambar 1 pelaksanaan model pembelajaran kooperatif tipe jigsaw modifikasi dijelaskan sebagai berikut: 1) setiap kelompok asal sudah ditetapkan anggota yang akan menjadi kelompok ahli di setiap praktikum yang akan dilakukan, 2) kelompok ahli dari masing-masing kelompok asal bergabung melakukan praktikum yang menjadi keahlianya, 3) kemudian pada pertemuan selanjutnya praktikum akan dilakukan oleh kelompok asal, jika tidak bisa dilakukan keseluruhan percobaan, maka dalam 1 kali pertemuan, hanya 2 praktikum yang dapat dilakukan oleh kelompok asal, 4) setiap praktikum yang dilakukan oleh kelompok asal, maka kelompok ahli dari judul praktikum tersebut akan membantu dalam kegiatan praktikum, 5) setelah selesai kelompok asal praktikum dari judul pertama, akan berlanjut ke judul selanjutnya dengan ahli selanjutnya, sehingga masing-masing anggota kelompok asal akan mendapatkan kesempatan menjadi ahli di setiap praktikum dan begitu seterusnya untuk praktikum berikutnya.

Berdasarkan uraian di atas, rumusan masalah dalam peneliti ini adalah "Apakah terdapat pengaruh penerapan LKS eksperimen berbasis pendekatan scientific melalui ICT dalam model pembelajaran kooperatif tipe jigsaw modifikasi terhadap pencapaian kompetensi pengetahuan dan kompetensi keterampilan siswa kelas X MIA SMAN 6 Padang?

\section{METODE PENELITIAN}

Jenis penelitian yang dilakukan adalah quasi eksperimen (eksperimen semu) dengan rancangan penelitian Randomized Control-Group only Design untuk melihat pengaruh penerapan LKS eksperimen melalui ICT dalam model pembelajaran kooperatif tipe jigsaw modifikasi. Populasi merupakan seluruh subjek dalam penelitian yang mempunyai kualitas dan karakteristik tertentu yang ditetapkan oleh peneliti untuk diteliti sehingga dapat ditarik kesimpulan. Populasi pada penelitian ini adalah siswa kelas X SMAN 6 Padang yang terdaftar pada semester ganjil tahun ajaran 2016/2017. Sampel merupakan sebagian dari populasi yang mewakili dari populasi tersebut dalam semua aspek atau karakteristik populasi. Sampel harus bersifat refresentatif artinya semua karakteristik populasi ada dalam sampel yang akan diteliti. Pengambilan sampel dilakukan secara purposive sampling. Sampel terdiri dari 2 kelas yaitu kelas eksperimen dan kelas kontrol. Setelah didapatkan dua kelas sampel, sampel dianalisis dengan uji kesamaan dua rata-rata untuk mengetahui kemampuan awal dari kelas sampel. Setelah didapatkan hasil analisis menggunakan uji kesamaan dua rata-rata, untuk menentukan kelas eksperimen dan kelas kontrol dilakukan pengundian secara random menggunakan mata uang. Sampel yang terpilih adalah kelas X MIA 4 sebagai kelas eksperimen dan kelas X MIA 5 sebagai kelas kontrol.

Dalam penelitian ini terdapat tiga variabel penelitian, yaitu: 1) variabel bebas yaitu LKS eksperimen berbasis pendekatan scientific melalui $\mathrm{ICT}^{[9]}$, 2) variabel terikat yaitu pencapaian kompetensi fisika siswa kelas X MIA SMAN 6 Padang yang meliputi kompetensi sikap, kompetensi pengetahuan, dan kompetensi keterampilan, 3) variabel kontrol yaitu model kooperatif tipe jigsaw modifikasi, guru mata pelajaran, materi pembelajaran, jumlah dan jenis soal, serta suasana belajar. Dalam kegiatan penelitian ini melalui tiga tahap yaitu tahap persiapan, pelaksanaan, dan penyelesaian. Dari ketiga tahap tersebut yang berbeda adalah pada tahap pelaksanaan. Tahap persiapan yang dilakukan adalah menyiapkan perangkat pembelajaran serta instrumen yang digunakan dalam penelitian. Tahap pelaksanaan yang 
dilakukan adalah melakukan penelitian terhadap kedua sampel yang terpilih dengan menerapkan sesuai rencana pelaksanaan pembelajaran yang telah disiapkan sebelumnya, yaitu menerapkan LKS eksperimen berbasis pendekatan scientific melalui ICT dalam model pembelajaran kooperatif tipe jigsaw modifikasi di kelas eksperimen. Tahap penyelesaian adalah menganalisis data-data yang telah didapatkan saat penelitian. Instrumen penelitian ini mencakup pada kompetensi sikap, pengetahuan, dan keterampilan. Penilaian pada kompetensi sikap dilakukan untuk mengetahui sikap siswa selama proses pembelajaran dengan instrumen berupa lembaran observasi kompetensi sikap. Instrumen kompetensi pengetahuan dalam penelitian ini adalah lembaran tes objektif yang jenisnya multiple choice test yang dilaksanakan di akhir penelitian. Agar tes ini menjadi alat ukur yang baik, maka dilakukan tes uji coba soal. Soal yang dipakai untuk penelitian ini adalah soal yang valid, reliabilitas tes dengan klasifikasi sangat tinggi, tingkat kesukaran soal dengan klasifikasi sedang dan daya beda soal dengan klasifikasi diterima. Selanjutnya, penilaian pada kompetensi keterampilan dilakukan selama proses kegiatan praktikum berlangsung dengan mengacu pada lembar penilaian unjuk kerja.

Data dari ketiga kompetensi dianalisis untuk menguji kebenaran hipotesis yang diajukan dalam penelitian. Teknik analisis data untuk kompetensi sikap menggunakan deskripsi dan grafik, untuk kompetensi pengetahuan dan kompetensi keterampilan dianalisis menggunakan uji kesamaan dua rata-rata. Sebelum dilakukan uji kesamaan dua rata-rata dilakukan terlebih dahulu uji normalitas dan uji homogenitas untuk mengetahui apakah sampel berasal dari populasi terdistribusi normal dan apakah memiliki varians yang homogen. Data dari kedua kelas sampel dikatakan berasal dari populasi yang terdistribusi normal, jika nilai $\mathrm{L}_{0}$ lebih kecil dari nilai $\mathrm{L}_{\mathrm{t}}$ dan data pada kedua kelas sampel dikatakan memiliki varians yang homogen jika nilai $F_{h}$ lebih kecil dari nilai $F_{t}$. Untuk mengetahui berapa besar pengaruh dari penerapan LKS eksperimen melalui ICT dalam model pembelajaran kooperatif tipe jigsaw modifikasi digunakan uji regresi linear sederhana.

\section{HASIL PENELITIAN DAN PEMBAHASAN}

\section{Hasil Penelitian}

Data yang dianalisis dalam penelitian ini mencangkup tiga kompetensi yaitu kompetensi sikap, pengetahuan, dan keterampilan. Data kompetensi sikap diperoleh selama proses pembelajaran tatap muka di dalam kelas melalui lembar observasi, data kompetensi pengetahun diperoleh melalui tes tertulis berupa posttest diakhir pembelajaran, dan data kompetensi keterampilan diperoleh selama kegiatan praktikum melalui rubrik penskoran pada unjuk kerja.

\section{a. Kompetensi Sikap}

Perolehan nilai kompetensi sikap setelah dianalisis untuk delapan kali pertemuan pada kedua kelas sampel dapat dilihat pada Tabel 1:

Tabel 1. Nilai Rata-Rata Kompetensi Sikap Setiap Pertemuan Kelas Eksperimen dan Kelas Kontrol

\begin{tabular}{|c|c|c|c|c|c|c|c|c|c|c|c|c|c|c|}
\hline \multirow{3}{*}{ Pert } & \multicolumn{14}{|c|}{ Aspek penilaian } \\
\hline & \multicolumn{2}{|c|}{ Spritual } & \multicolumn{2}{|c|}{ Kerja Sama } & \multicolumn{2}{|c|}{ Disiplin } & \multicolumn{2}{|c|}{ Jujur } & \multicolumn{2}{|c|}{$\begin{array}{c}\text { Rasa Ingin } \\
\text { Tahu }\end{array}$} & \multicolumn{2}{|c|}{$\begin{array}{c}\text { Tanggung } \\
\text { Jawab }\end{array}$} & \multicolumn{2}{|c|}{ Percaya Dir } \\
\hline & Eksp & Kont & Eksp & Kont & Eksp & Kont & Eksp & Kont & Eksp & Kont & Eksp & Kont & Eksp & Kont \\
\hline 1 & 75 & 75 & 72 & 70 & 74 & 73 & 74 & 67 & 65 & 66 & 78 & 75 & 77 & 70 \\
\hline 2 & 75 & 75 & 79 & 74 & 74 & 76 & 75 & 73 & 65 & 75 & 79 & 75 & 76 & 73 \\
\hline 3 & 75 & 75 & 81 & 76 & 76 & 81 & 76 & 75 & 78 & 77 & 76 & 75 & 76 & 74 \\
\hline 4 & 84 & 77 & 85 & 76 & 79 & 80 & 78 & 77 & 84 & 81 & 79 & 76 & 79 & 74 \\
\hline 5 & 100 & 79 & 85 & 79 & 82 & 80 & 79 & 76 & 87 & 83 & 82 & 77 & 79 & 76 \\
\hline 6 & 100 & 100 & 86 & 84 & 88 & 85 & 80 & 80 & 88 & 85 & 86 & 77 & 80 & 76 \\
\hline 7 & 100 & 100 & 90 & 87 & 88 & 87 & 89 & 83 & 88 & 86 & 88 & 84 & 83 & 81 \\
\hline 8 & 100 & 100 & 90 & 88 & 97 & 89 & 90 & 86 & 96 & 88 & 90 & 88 & 88 & 87 \\
\hline \begin{tabular}{|l|} 
Rata- \\
Rata \\
\end{tabular} & 88,6 & 85,133 & 83,364 & 79,167 & 82,169 & 81,25 & 80,147 & 76,989 & 81,434 & 80,114 & 82,261 & 78,31 & 79,87 & 76,52 \\
\hline Rat & dalda & $1 \mathrm{Tlla}$ & speri & & & & & & 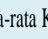 & & & & 79 & 9,64 \\
\hline
\end{tabular}

Berdasarkan Tabel 1 dapat dilihat bahwa nilai kompetensi sikap untuk setiap indikator penilaian pada setiap pertemuan cenderung mengalami peningkatan baik kelas eksperimen maupun kelas kontrol, tetapi pada beberapa pertemuan nilai kelas eksperimen dan kelas kontrol konstan atau tetap. Rata-rata nilai sikap kelas eksperimen lebih tinggi dibandingkan kelas kontrol untuk tujuh aspek yang diukur, tetapi pada setiap pertemuan untuk masingmasing indiktor penilaian, tidak selalu kelas eksperimen yang nilainya lebih tinggi dibanding kelas kontrol, beberapa pertemuan dan beberapa indikator penilaian justru nilai kelas kontrol lebih tinggi dibandingkan kelas eksperimen. Data kompetensi sikap dianalisis menggunakan grafik, dapat dilihat pada Gambar 2.

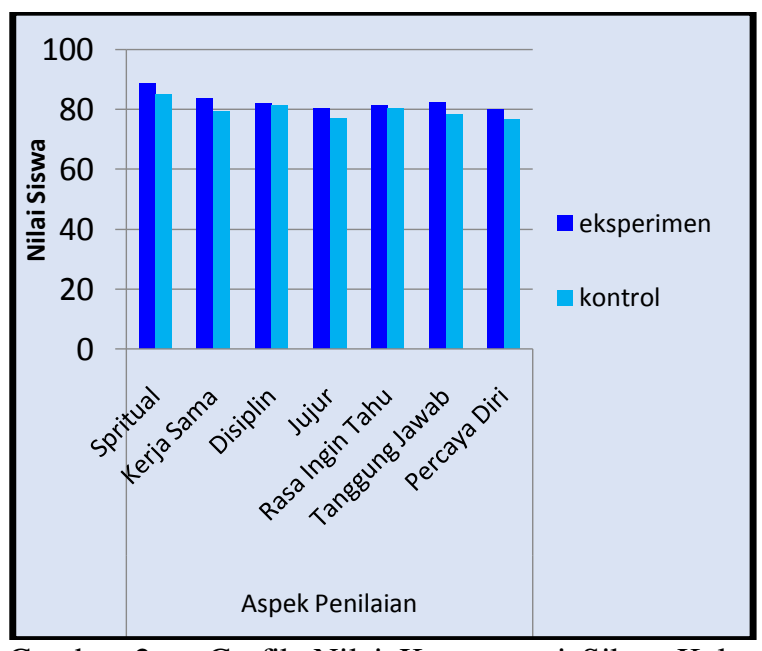

Gambar 2. Grafik Nilai Kompetensi Sikap Kelas Eksperimen dan Kelas Kontrol Setiap Aspek Penilaian

Berdasarkan Gambar 2 dapat dilihat bahwa nilai rata-rata kompetensi sikap kelas eksperimen 
untuk setiap aspek penilaian berbeda dari kelas kontrol. Jadi, berdasarkan analisis menggunakan grafik, dapat ditarik kesimpulan bahwa terdapat perbedaan nilai kompetensi sikap kelas eksperimen dengan kelas kontrol.

\section{b. Kompetensi Pengetahuan}

Deskripsi data kompetensi pengetahuan dapat dilihat pada Tabel 2.

Tabel 2. Deskripsi Nilai Kompetensi Pengetahuan Kelas Eksperimen dan Kelas Kontrol di SMAN 6 Padang

\begin{tabular}{|c|c|c|}
\hline & $\begin{array}{c}\text { Kelas } \\
\text { Eksperimen }\end{array}$ & $\begin{array}{c}\text { Kelas } \\
\text { Kontrol }\end{array}$ \\
\hline $\mathrm{N}$ & 31 & 31 \\
\hline Mean & 68,04 & 60,65 \\
\hline Std. Deviation & 6,15 & 8,38 \\
\hline Variance & 37,84 & 70,24 \\
\hline Minimum & 53 & 47 \\
\hline Maximum & 80 & 77 \\
\hline Sum & 2109 & 1880 \\
\hline
\end{tabular}

Berdasarkan Tabel 2 dapat dilihat bahwa nilai ratarata kompetensi pengetahuan kelas eksperimen 68,04 , nilai rata-rata untuk kelas kontrol 60,65, standar deviasi kelas eksperimen 6,15, standar devisi kelas kontrol 8,38 nilai minimum dan maksimum kelas eksperimen 53 dan 80, nilai maksimum dan minimum kelas kontrol 47 dan 77. Data yang diperoleh rata-rata nilai kelas eksperimen lebih tinggi dibandingkan dengan rata-rata kelas kontrol.

Pada kompetensi pengetahuan untuk mengetahui perbedaan kompetensi pengetahuan antara kelas eksperimen dengan kelas kontrol dilakukan uji kesamaan dua rata-rata. Sebelum melakukan uji kesamaan dua rata-rata terlebih dahulu dilakukan uji normalitas dan homogenitas. Uji normalitas menggunakan uji liliefors didapatkan hasil bahwa kelas eksperimen dan kelas kontrol mempunyai nilai $\mathrm{L}_{0}<\mathrm{L}_{t}$ pada taraf nyata 0,05 , berarti data kelas eksperimen dan kelas kontrol terdistribusi normal. Kemudian dilakukan uji homogenitas menggunakan uji $\mathrm{F}$ didapatkan hasil bahwa $F_{h}=1,86$ dan $F_{t}$ dengan taraf nyata $\alpha=0,05$ $d k_{\text {pembilang }}$ (30) dan $\mathrm{dk}_{\text {penyebut }}$ (30) adalah 1,84. Hasil perhitungan tersebut menunjukkan bahwa $F_{h}>F_{(0,05) ;(30,30)}$, hal ini berarti data kedua kelas sampel mempunyai varians yang tidak homogen.

Setelah melakukan uji normalitas dan uji homogenitas didapatkan bahwa masing-masing kelas sampel terdistribusi normal dan tidak homogen sehingga analisis data yang digunakan adalah uji kesamaan dua rata-rata dengan uji t'. Hasil uji hipotesis menggunakan uji t' adalah nilai t' untuk kompetensi pengetahuan pada taraf nyata 0,05 didapatkan 3,96, sedangkan nilai $\mathrm{t}_{\text {tabel }}$ diperoleh 2,00 pada derajat kebebasan 62 dengan taraf nyata 0,05 . Berdasarkan data uji t' yang diperoleh menunjukan bahwa t' berada di luar daerah penerimaan $\mathrm{H}_{\mathrm{o}}$ artinya
Hi diterima, berarti terdapat perbedaan kompetensi pengetahuan kelas eksperimen dengan kelas kontrol. Perbedaan tersebut karena ada pengaruh penerapan LKS eksperimen berbasis pendekatan scientific melalui ICT dalam model pembelajaran kooperatif tipe jigsaw modifikasi terhadap pencapaian kompetensi pengetahuan siswa.

Untuk mengetahui besarnya pengaruh penerapan LKS eksperimen berbasis pendekatan scientific melalui ICT terhadap kompetensi pengetahuan dilakukan uji regresi linear sederhana dengan persamaan yang diperoleh adalah:

$$
\hat{\mathrm{Y}}=\mathrm{a}+\mathrm{bX}=75,37-0,085 \mathrm{X}
$$

Sedangkan uji keberartian dan uji linearitas dapat dibantu dengan Tabel Anava.

Tabel 3. Anava untuk Regresi Kompetensi

Pengetahuan

\begin{tabular}{|c|c|c|c|c|}
\hline \multicolumn{5}{|l|}{ Sumber } \\
\hline Variansi & $\mathrm{dk}$ & JK & KT & $\mathrm{F}$ \\
\hline Total & 31 & 144744,44 & 144744,44 & \\
\hline $\begin{array}{c}\text { Koefesien } \\
\text { (a) }\end{array}$ & 1 & 143616,13 & 143616,129 & $\begin{array}{l}\mathrm{Fh}= \\
0,867 \\
\mathrm{Ft}=4,18 \\
\mathrm{Fh}<\mathrm{Ft}\end{array}$ \\
\hline $\begin{array}{l}\text { Regresi } \\
\text { (b/a) }\end{array}$ & 1 & 4,419 & 4,419 & \\
\hline Sisa & 29 & 1123,896 & 38,3755 & \\
\hline $\begin{array}{c}\text { Tuna } \\
\text { Cocok }\end{array}$ & 16 & $-4,419$ & $-0,276$ & \\
\hline Galat & 13 & 1128,315 & 86,793 & $\begin{array}{l}\mathrm{Fh}= \\
-0,003 \\
\mathrm{Ft}=2,70 \\
\mathrm{Fh}<\mathrm{Ft} \\
\mathrm{rh}= \\
0,06\end{array}$ \\
\hline
\end{tabular}

Berdasarkan Tabel 3 dapat dilihat bahwa untuk uji keberartian didapatkan nilai $\mathrm{F}_{\text {hitung }}=0,867$, sedangkan nilai $F_{\text {tabel }}=4,17$. Berdasarkan nilai $F_{\text {hitung }}$ dan $F_{\text {tabel }}$ yang diperoleh, nilai $F_{\text {hitung }}$ lebih kecil dari nilai $F_{\text {tabel }}$ artinya koefisien arah regresi tidak berarti. Untuk uji linearitas didapatkan nilai $\mathrm{F}_{\text {hitung }}$ sama dengan -0,003, sedangkan nilai $F_{\text {tabel }}$ sama dengan 2,34. Berdasarkan nilai $F_{\text {hitung }}$ dan $F_{\text {tabel }}$ yang diperoleh, nilai $F_{\text {hitung }}$ lebih kecil dari nilai $F_{\text {tabel }}$ artinya regresi linear. Untuk uji hubungan antara dua variabel didapat $r_{\text {hitung }}$ sama dengan 0,06, sedangkan $r_{\text {tabel }}$ sama dengan 0,349. Berdasarkan nilai $r_{\text {hitung }}$ dan $r_{\text {tabel }}$ yang diperoleh, nilai $r_{\text {hitung }}$ lebih kecil dari nilai $r_{\text {tabel }}$, ini berarti tidak terdapat hubungan antara LKS eksperimen berbasis pendekatan scientific melalui ICT dalam model pembelajaran kooperatif tipe jigsaw modifikasi terhadap pencapaian kompetensi pengetahuan.

\section{c. Kompetensi Keterampilan}

Pada kompetensi keterampilan, didapatkan deskripsi data seperti Tabel 4. 
Tabel 4. Deskripsi Nilai Kompetensi Keterampilan untuk Kelas Eksperimen dan Kelas Kontrol di SMAN 6 Padang

\begin{tabular}{|c|c|c|}
\hline & $\begin{array}{c}\text { Kelas } \\
\text { Eksperimen }\end{array}$ & $\begin{array}{c}\text { Kelas } \\
\text { Kontrol }\end{array}$ \\
\hline $\mathrm{N}$ & 31 & 31 \\
\hline Mean & 86,54 & 81,64 \\
\hline Std. Deviation & 5,67 & 3,90 \\
\hline Variance & 32,17 & 15,18 \\
\hline Minimum & 74 & 74 \\
\hline Maximum & 96 & 88 \\
\hline Sum & 2683 & 2530,96 \\
\hline
\end{tabular}

Berdasarkan Tabel 4 dapat dilihat bahwa nilai ratarata kelas eksperimen lebih tinggi dibandingkan dengan rata-rata kelas kontrol. Deskripsi data kompetensi keterampilan dianalisis menggunakan uji kesamaan dua rata-rata. Sebelum dianalisis menggunakan uji kesamaan dua rata-rata, terlebih dahulu melakukan uji normalitas dan uji homogenitas. Uji normalitas menggunakan uji lilieford didapatkan hasil bahwa kelas eksperimen dan kelas kontrol mempunyai nilai $L_{o}<L_{t}$ pada taraf nyata 0,05 , berarti data hasil tes unjuk kerja kelas eksperimen dan kelas kontrol terdistribusi normal. Kemudian dilakukan uji homogenitas menggunakan uji F didapatkan hasil bahwa $F_{\text {hitung }}=2,12$ dan $F_{\text {tabel }}$ dengan taraf nyata $\alpha=0,05$ pada $d k_{\text {pembilang }}$ (30) dan $d k_{\text {penyebut }}(30)$ adalah 1,86 . Hasil ini menunjukkan

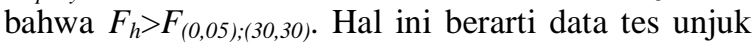
kerja kedua kelas sampel mempunyai varians yang tidak homogen.

Setelah melakukan uji normalitas dan uji homogenitas didapatkan bahwa masing-masing kelas sampel terdistribusi normal dan tidak homogen sehingga analisis data yang digunakan adalah uji kesamaan dua rata-rata dengan uji t'. Hasil uji hipotesis kelas sampel pada kompetensi pengetahuan adalah nilai t' untuk kompetensi keterampilan dengan taraf nyata 0,05 didapatkan 3,96 dan nilai $\mathrm{t}_{\text {tabel }}$ adalah 2,00 berdasarkan tabel uji t' pada derajat kebebasan 62 dengan taraf nyata 0,05 . Berdasarkan data uji t' dapat dikemukakan bahwa t' berada di luar daerah penerimaan $\mathrm{H}_{\mathrm{o}}$ maka Hi diterima, berarti pada kelas eksperimen dan kelas kontrol terdapat perbedaan kompetensi keterampilan kelas eksperimen dengan kelas kontrol. perbedaan tersebut karena ada pengaruh penerapan LKS eksperimen berbasis pendekatan scientific melalui ICT dalam model pembelajaran kooperatif tipe jigsaw modifikasi terhadap pencapaian kompetensi keterampilan siswa. Untuk mengetahui besarnya pengaruh penerapan LKS eksperimen berbasis pendekatan scientific melalui ICT terhadap kompetensi keterampilan, dapat menggunakan uji regresi linear sederhana dengan persamaan sebagai berikut:

$$
\hat{\mathrm{Y}}=\mathrm{a}+\mathrm{bX}=1,209 \mathrm{X}-17,257
$$

Sedangkan uji keberartian dan uji linearitas dapat dibantu dengan Tabel Anava.
Tabel 5. Anava untuk Regresi Kompetensi Keterampilan

\begin{tabular}{|c|c|c|c|c|}
\hline $\begin{array}{l}\text { Sumber } \\
\text { Variansi }\end{array}$ & $\mathrm{dk}$ & JK & KT & $\mathrm{F}$ \\
\hline Total & 31 & 229931,25 & 229931,25 & \\
\hline $\begin{array}{c}\text { Koefesien } \\
\text { (a) }\end{array}$ & 1 & $\begin{array}{c}232958,67 \\
4\end{array}$ & $\begin{array}{c}232958,67 \\
4\end{array}$ & \multirow[t]{3}{*}{$\begin{array}{l}\mathrm{Fh}= \\
391,487 \\
\mathrm{Ft}= \\
4,18 \\
\mathrm{Fh}>\mathrm{Ft}\end{array}$} \\
\hline $\begin{array}{l}\text { Regresi } \\
\text { (b/a) }\end{array}$ & 1 & 894,240 & 894,240 & \\
\hline Sisa & 29 & 66,242 & 2,284 & \\
\hline $\begin{array}{c}\text { Tuna } \\
\text { Cocok }\end{array}$ & 16 & $-894,240$ & $-55,890$ & \\
\hline Galat & 13 & 960,482 & 73,883 & $\begin{array}{l}\mathrm{Fh}= \\
-0,756 \\
\mathrm{Ft}= \\
2,70 \\
\mathrm{Fh}<\mathrm{Ft} \\
\mathrm{r} \mathrm{h}= \\
0,965\end{array}$ \\
\hline
\end{tabular}

Berdasarkan hasil analisis Tabel 5, untuk uji keberartian didapatkan nilai $F_{\text {hitung }}$ sama dengan 391,487, sedangkan nilai $F_{\text {tabel }}$ sama dengan 4,17 . Berdasarkan nilai $\mathrm{F}_{\text {hitung }}$ dan $\mathrm{F}_{\text {tabel }}$ yang diperoleh, nilai $F_{\text {hitung }}$ lebih besar dari nilai $F_{\text {tabel }}$, artinya koefisien arah regresi berarti. Untuk uji linearitas didapatkan nilai $F_{\text {hitung }}$ sama dengan $-0,756$ sedangkan nilai $F_{\text {tabel }}$ sama dengan 2,34. Berdasarkan nilai $F_{\text {hitung }}$ dan $F_{\text {tabel }}$ yang diperoleh, nilai $F_{\text {hitung }}$ lebih kecil dari nilai $F_{\text {tabel }}$ artinya regresi linear. Untuk uji hubungan antara dua variabel didapat $r_{\text {hitung }}$ sama dengan 0,965 , sedangkan $r_{\text {tabel }}$ sama dengan 0,349. Berdasarkan nilai $r_{\text {hitung }}$ dan $r_{\text {tabel }}$ yang diperoleh, nilai $r_{\text {hitung }}$ lebih besar dari nilai $\mathrm{r}_{\text {tabel}}$, ini berarti terdapat hubungan antara LKS eksperimen berbasis pendekatan scientific melalui ICT dalam model pembelajaran kooperatif tipe jigsaw modifikasi terhadap pencapaian kompetensi pengetahuan. Untuk mengetahui besar pengaruh LKS eksperimen berbasis pendekatan scientific melalui ICT terhadap pencapaian kompetensi keterampilan siswa maka dihitung koefisien determinasinya. Dari hasil perhitungan didapat nilai koefisien determinasi sebesar 93,10\%. Nilai ini artinya 93,10\% pada kompetensi keterampilan dipengaruhi oleh penggunaan LKS eksperimen berbasis pendekatan scientific melalui ICT dalam model pembelajaran kooperatif tipe jigsaw modifikasi.

Pada kompetensi keterampilan, dalam penelitian selain analisis data unjuk kerja menggunakan uji kesamaan dua rata-rata dan uji regresi linear sederhana, juga dianalisis menggunakan grafik. Hasil analisis data unjuk kerja menggunakan grafik dapat dilihat pada Gambar 3. 


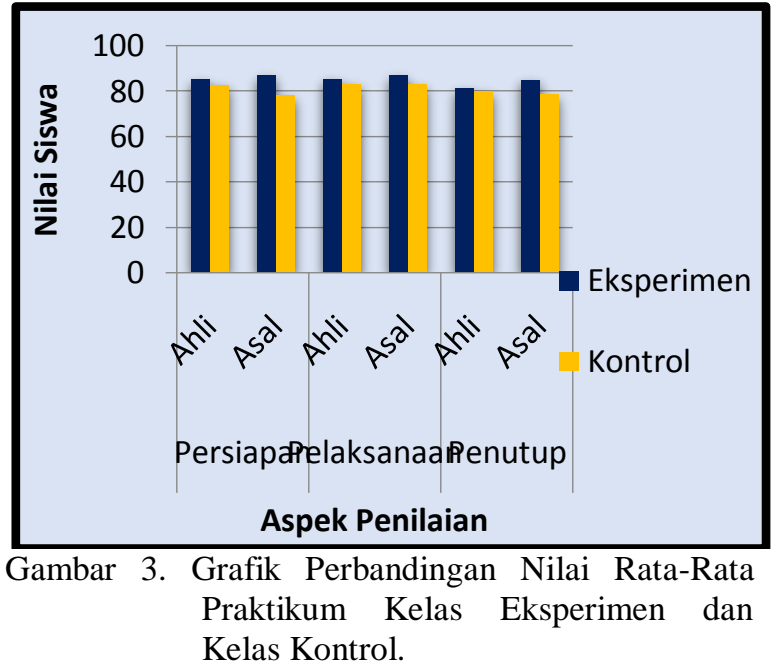

Berdasarkan Gambar 3 dapat dilihat bahwa nilai ratarata setiap praktikum untuk 3 aspek penilaian (persiapan, pelaksanaan, dan penutup) kelompok ahli dan kelompok asal kelas eksperimen lebih tinggi dibandingkan kelas kontrol.

\section{Pembahasan}

Berdasarkan hasil analisis untuk kompetensi sikap menggunakan deskripsi dan grafik untuk kedua kelas sampel diperoleh hasil bahwa kelas eksperimen memiliki sikap yang baik dibandingkan kelas kontrol. Hal tersebut terlihat pada grafik perbandingan nilai kompetensi sikap kelas eksperimen dengan kelas kontrol. Pada penilaian kompetensi sikap untuk aspek penilaian sikap spritual kelas eksperimen dan kelas kontrol mengalami peningkatan dan pada beberapa minggu cenderung tidak berubah atau konstan. Aspek penilaian dibatasi pada sikap mengucapkan salam, bersyukur dan mengaji. Secara rata-rata terdapat perbedaan nilai sikap spritual kedua kelas sampel.

Pada kompetensi sikap, terdapat perbedaan nilai rata-rata sikap sosial kedua kelas sampel untuk masing-masing aspek penilaian seperti kerja sama, disiplin, jujur, rasa ingin tahu, tanggung jawab, percaya diri. Penilaian masing-masing aspek sosial untuk setiap minggu juga mengalami perubahan. Nilai kompetensi sikap kelas eksperimen berbeda dari kelas kontrol, hal ini dikarenakan kebiasaankebiasaan yang dilakukan oleh guru selama proses pembelajaran berlangsung. Pembentukan karakter oleh guru untuk kedua kelas sampel menunjukan karakter yang terbentuk semakin lama semakin baik.

Ditinjau dari kompetensi pengetahun terdapat perbedaan antara kelas eksperimen dengan kelas kontrol. Hal ini mengindikasikan bahwa LKS eksperimen berbasis pendekatan scientific melalui ICT memberikan efek terhadap kompetensi pengetahuan siswa. Efek yang tampak dari penggunaan LKS eksperimen tersebut adalah siswa lebih semangat dan termotivasi menggunakan LKS eksperimen berbasis pendekatan scientific melalui ICT, karena siswa mudah menerima pembelajaran dengan mengamati animasi-animasi, video praktikum, LKS eksperimen, dan kuis interaktif. Di samping itu, LKS eksperimen melalui ICT ini siswa dapat belajar secara mandiri karena materi dalam LKS eksperimen dapat diakses siswa melalui HP ataupun laptop sehingga siswa dapat mempelajari LKS eksperimen dimana dan kapan saja. Dalam pembelajaran online, pengajar perlu membantu peserta didik mengembangkan strategi untuk mengerjakan pekerjaan mereka secara efisien dan memperoleh informasi dan keterampilan yang mereka butuhkan untuk melengkapi pelajarannya ${ }^{[3]}$. Keadaan seperti ini memudahkan siswa untuk memahami materi-materi yang ada dalam ICT.

LKS eksperimen yang ada di dalam ICT sesuai dengan langkah-langkah pendekatan scientific supaya siswa paham dengan berfikir ilmiah. Pengamatan yang dituntut dalam LKS adalah memahami materi keseluruhan baik pengamatan terhadap animasi, video, dan animasi virtual. Hal ini membuat siswa lebih kreatif dalam penggunaan LKS eksperimen yang diberikan. Langkah pertanyaan yang diajukan dalam LKS mengacu kepada apa yang diamati sehingga hasil pengamatan siswa dapat menjadi pertanyaan dalam proses pembelajaran. Langkah scientific berikutnya yaitu mencari informasi dengan melakukan kegiatan praktikum di laboratorium. Dengan adanya LKS seperti ini memungkin siswa memahami melakukan kegiatan praktikum yang lebih baik.

Walaupun sudah terdapat perbedaan yang nyata antara kompetensi pengetahuan siswa kelas eksperimen dan kelas kontrol, namun nilai rata-rata kompetensi pengetahuan yang diperoleh siswa masih di bawah Kriteria Ketuntasan Minimal (KKM) yang ditetapkan, hal ini disebabkan karena masih banyak siswa yang belum mampu memahami secara baik LKS eksperimen berbasis pendekatan scientific, apalagi ditambah dengan sering terganggunya jaringan online [11]. Kendala yang dihadapi peneliti sesuai dengan penelitian yang dilakukan oleh peneliti lain yang mengungkapkan bahwa dalam pelaksanaan pembelajaran ICT, saat pembelajaran berlangsung, siswa akan menggunakan koneksi internet secara bersamaan sehingga akan membuat siswa terhubung ke pembelajaran ICT dengan waktu yang cukup lama dikarenakan koneksi internet lambat ${ }^{[10]}$. Selain hal tersebut, penyesuaian menggunakan model pembelajaran yang selama ini terbiasa dengan metode ceramah membutuhkan waktu yang lama, kurang antusias dalam mengikuti model pembelajaran dengan model pembelajaran kooperatif tipe jigsaw modifikasi dikarenakan siswa merasa asing dengan model tersebut. Siswa masih bingung dengan peranan kelompok asal dan kelompok ahli, Siswa mengulur waktu saat praktikum dan mengumpulkan hasil kegiatan praktikum sehingga pelaksanaan pembelajaran tidak tepat waktu. Berdasarkan uji pengaruh menunjukkan bahwa besar 
pengaruh LKS eksperimen berbasis pendekatan scientific melalui ICT dalam model pembelajaran kooperatif tipe jigsaw modifikasi sebesar 0,39\%, hal ini menunjukkan bahwa $99,71 \%$ kompetensi pengetahuan dipengaruhi oleh yang lain. Keadaan ini mengindikasikan bahwa LKS eksperimen bukanlah satu-satunya faktor yang mempengaruhi kompetensi Fisika siswa[12].

Pada kompetensi keterampilan, setelah dianalisis menggunakan uji kesamaan dua rata-rata dengan statistik uji t'didapatkan hasil bahwa terdapat perbedaan anatara kelas eksperimen dengan kelas kontrol, artinya LKS eksperimen berbasis pendekatan scientific melalui ICT memiliki pengaruh terhadap kompetensi keterampilan. Besar pengaruh LKS eksperimen berbasis pendekatan scientific dalam model pembelajaran kooperatif tipe jigsaw adalah 93,10\%. Hal ini karena di dalam ICT ada materi, LKS eksperimen, animasi berhubungan dengan hipotesis praktikum dalam LKS eksperimen, dan video yang berisi petunjuk dalam praktikum sehingga memudahkan siswa dalam melaksanakan praktikum. LKS eksperimen melalui ICT tersebut juga dilengkapi dengan langkah-langkah scientific yang menuntun siswa melaksanakan percobaan secara sistematis. Sedangkan di kelas kontrol menggunakan LKS yang ada di sekolah yang berisi sedikit sekali yang membahas tentang kegiatan praktikum, hanya ada judul, alat dan bahan dan langkah percobaan. Selain itu dikelas kontrol LKS dalam kegiatan praktikum yang digunakan tidak ada animasi dan video petunjuk praktikum yang dapat membantu dalam kegiatan praktikum. Hal ini LKS eksperimen berbasis pendekatan scientific melalui ICT dapat menunjang siswa dalam melakukan praktikum seperti dalam melakukan analisis data praktikum dan menyimpulkan praktikum.

\section{KESIMPULAN}

Berdasarkan analisis dan pembahasan yang telah diuraikan, dapat ditarik kesimpulan sebagai berikut:

1. Terdapat perbedaan kompetensi sikap kelas eksperimen dengan kelas kontrol selama proses pembelajaran.

2. Terdapat pengaruh dari penerapan LKS eksperimen berbasis pendekatan scientific melalui ICT dalam model pembelajaran kooperatif tipe jigsaw modifikasi terhadap pencapaian kompetensi pengetahuan dan kompetensi keterampilan siswa kelas X MIA SMAN 6 Padang pada taraf signifikansi 95\%.

3. Besarnya pengaruh dari penerapan LKS eksperimen berbasis pendekatan scientific melalui ICT dalam model pembelajaran kooperatif tipe jigsaw modifikasi terhadap pencapaian kompetensi pengetahuan sebesar $0,39 \%$ dan pada pencapaian kompetensi keterampilan sebesar $93,10 \%$ pada taraf signifikansi $95 \%$

\section{DAFTAR PUSTAKA}

[1] Depdiknas. 2007. Standar Isi Untuk Satuan Pendidikan Dasar dan Menengah. Jakarta : Depdiknas.

[2] Depdiknas. 2008. Panduan Pengembagan Bahan Ajar. Jakarta: Direktorat Jendral Manajemen Pendidikan Dasar dan Menengah.

[3] Munir. 2008. Kurikulum Berbasis Teknologi Informasi dan komunikasi. Jakarta: Alfabeta.

[4] Rusman. 2013. Model-model Pembelajaran: Mengembangkan Profesionalisme Guru. Jakarta: Rajawali press.

[5] Lie, Anita.2002. Cooperative Learning. Jakarta: Gramedia Widiasarana Indonesia

[6] Khan, Gul Nazir. Effect Of Jigsaw Technique Of Cooperative Learning (JCL) Academic Achievement Of Secondary School Students. Global Advancer Reasearch Journl of Education Research and Review (ISSN: 2315-513) Vol 5(2), PP (02-031, February, 2016).

[7] Zakaria, Effandi, Solfitri, Titi, Daud, Yosoff, Abidin, Z.Z. Effect of Cooperative Learning on Secondary School Students Mathematic Achivement. Creative Eduacation, 2013 Vol 4 No 2, 98-100.

[8] Slavin, Robert E. 2009. Coopererative Learning, teori, riset, dan praktik. Bandung: NusaMedia.

[9] Masril, Hidayati. 2015. Pengembangan Bahan Ajar Berbasis Scientific Approach Melalui ICT Untuk Menunjang Implementasi Kurikulum 2013 dalam Mata Pelajaran Fisika SMA (Laporan Penelitian HB tahun I). Padang: UNP.

[10]Hidayati, Masril, Gisti Vilara. 2016. Pengembangan Bahan Ajar Fisika Melalui ICT Menggunakan Software Moodle Untuk SMA Kelas $X$. Prosiding SEMIRATA bidang MIPA 2016: BKS-PTS Barat, Palembang 22-24 Mei 2016.

[11] Masril, Hidayati, 2015. Perancangan Bahan Ajar Berbasis Scientific Approach Untuk Mata Pelajaran Fisika Sma Kelas X, Jurnal Eksakta 1, Hal . 102

[12] Masril, Hidayati, 2014, Perancangan Bahan Ajar Berbasis Scientific Approach Untuk Mata Pelajaran Fisika Sma Kelas X, Jurnal PILLAR OF PHYSICS EDUCATION 3(1). 